\title{
Integration of Ozone Therapy for head and neck infective and chronic disease
}

\author{
Philip Mollica
}

RockMoll Dental, Saddle Brook, NJ. USA.

\section{ABSTRACT}

\section{OOPEN ACCESS}

\section{Citation \\ Mollica P. Integration of Ozone Therapy for head and neck infective and chronic disease [abstract]. Proceedings of the 5Th WFOT Meeting; $2016 \mathrm{Nov}$ 18-20; Mumbai, India. J Ozone Ther. 2018;2(2). doi: 10.7203/ jo3t.2.2.2018.11133}

\section{Academic Editor}

Jose Baeza-Noci, School of Medicine, Valencia University, SPAIN

\section{Editor}

World Federation of Ozone Therapy, Bolgna, ITALY

\section{Received}

December 10, 2017

\section{Accepted}

December 11, 2017

\section{Published}

March 4, 2018

\section{Intellectual Property}

Philip Mollica. This is an open access article distributed under the terms of the Creative Commons Attribution License (CC BY 4.0), which permits unrestricted use, distribution, and reproduction in any medium, provided the original author and source are credited.

\section{Author Information}

drphilmollica@gmail.com
Introduction: Treatment and management of complex chronic disease states within the head and neck have traditionally been treated within the scope and philosophy of allopathic based dental/medical model. Success is therapeutically based upon three stanchions symptomology, pharmacology and surgical intervention. As with the successes of any therapeutic model some complications are possible. Symptomatic treatment does not address the root causality of the disease process. In addition, the patient can experience pharmaceutical side effects and post-surgical compilations such as infection and impaired healing processes. Ozone therapy as part of an Integrative Biologic Dental Medicine model has allowed for a paradigm shift in thinking and approach to the ever-growing problems of therapy resistant infection, aging population and chronic long term aliments $[1,2,3]$. The management of acute and chronic infective disease is a critical factor in the overall health and wellness of patients. The head and neck are principle areas of infective disease. Primary contributors to this issue are infections of odontogenic and/or osteogenic origins [4]. Ozone therapy has become one of the principle therapeutic modalities utilized in Integrative Biologic Dental Medicine 'IBDM'. The objective of this presentation will be to explain and demonstrate specifically how ozone therapy is utilized in dental medicine. Through specific micro-dosing and anatomic placement of ozone enhanced healing processes can occur [5]. Reparative osteogenesis is one corner stone in the restoration and maintenance of human jaw integrity [6]. Case presentations will be the demonstrative educational model by which comprehensive head and neck infection remediation and tissue repair occur for patients.

Material and methods: In 2011, Professor Olga Sonia Leon Fernandez, University of Havana, Cuba, presented at the European Ozone Congress what she calls "Fundamental Scientific facts about Medical Ozone" [7]. This information reinforced the previous work done by Dr. Renate ViebahnHansler and Dr. Velio Bocci. These fundamental facts are significant in that they can directly influence biologic systems on multiple levels in a positive way to support and enhance the patient's healing process $[1,8]$. These scientific facts include the following:

1. Disinfection properties: microbicidal effect (bactericide, fungicide, virostatic, parasiticidal)

2. Wound cleaning

3. Enhance wound healing

4. Activation of red blood cell metabolism with improved oxygen release, increase in ATP levels

5. Activation of immunocompetent cells and release of cytokines such as interferones and interleukins. 
6. Modulation of the immune system.

7. Increase in antioxidant capacity through activation of cellular antioxidants - (superoxide dismutase, catalase)

8. Anti-inflammatory effect

9. Endothelium cell increased release of nitric oxide

10. Equilibration of Redox Potential

11. Release of stem cells, autacoids and growth factors

Taking into consideration the multitude of positive therapeutic biologic effects ozone therapy has, one has to wonder if it is possible to support and enhance that process and ultimately improve the patient's outcome [9]. Development and incorporation of an educational and clinical model is a critical cornerstone for successful patient outcomes. Based upon the thesis of result based dental medicine, Integrative Biologic Dental Medicine was created. As a result guidelines based upon the low-dose concept of oxygen/ozone therapy can be integrated into the daily practice of dental medicine.

Conclusions: Integration of oxygen/ozone therapy into dental medicine is a paradigm shift for patient enhanced outcomes. Comprehensive understanding of the proper application and integration of this therapeutic modality is critical. This can only be achieved through proper training of the practitioner based upon a sound educational and philosophical model. Integrative Biologic Dental Medicine is an established educational and philosophical model that recognizes and welcomes emerging and established therapeutic modalities such as oxygen/ozone therapy.

\section{References:}

1. Viehban-Hansler R. The Use of Ozone in Medicine, 5th edition. Iffezheim: ODREI Pub; 2007.

2. Newman MG, Takei H, Klokkevold PR, Carranza FA. Carranza's clinical periodontology. Philadelphia: Elsevier health sciences; 2011.

3. Mollica P, Rockefeller K. Integrative Biologic Dental Medicine: Dental Medicine for the 21st Century. New Jersey: ACIMD Press; 2014.

4. Fouad AF. Endodontic infections and systemic disease. In: Endodontic microbiology. Hoboken, New Jersey: James Wiley \& Sons Inc; 2009.

5. Viehban-Hansler R, Fernandez O, Fahmi Z. Ozone in Medicine: The Low Dose Concept - Guidelines and Treatment Strategies. Ozone: Science and Engineering 2012;34(6):408-424.

6. Volozhin AI, Vasilev AI, Malyginov NN, Bulanova IM, Grigorian AS, Kiseleva EV, et al. Use of mesenchymal stem cells for reparative processes activation in bone jaw tissue in experimental conditions. Stomatologiia (Mosk) 2010;89(1):10-4.

7. Fernandez O. Fundamental scientific facts about Medical Ozone. Proceedings of European Ozone Congress. EUROCOOP. Vienna, Austria: 2011.

8. Bocci V. Ozone A New Medical Drug. Dordrecht, The Netherlands: Springer; 2005.

9. Mollica P, Harris R. Cyto-Immunologic Supportive Therapies for Ozone Therapy in Dentistry. New Jersey: ACIMD Press; 2007. 